\title{
An Analysis of the Environment and Personality Impact in Innovative Non-existent Projects
}

\author{
Bogdan Lent* \\ Faculty of Management \\ University of Science and Technology UTP \\ Bydgoszcz, Poland \\ bogdan.lent@utp.edu.pl
}

\author{
Helena Koscielniak, Katarzyna Lukasik, Katarzyna \\ Brendzel-Skowera \\ Faculty of Management \\ University of Technology $\mathrm{PCz}$ \\ Czestochowa, Poland
}

\begin{abstract}
Bootlegging projects (called for clarity Innovative non-existent Projects INP) engage substantial part of company's productive capabilities making any controlling based decisions less effective. However, they are the origins of some most famous innovations: Makrolon ${ }^{\circledR}$ and Aspirin ${ }^{\circledR}$ of Bayer AG, Post-it ${ }^{\circledR}$ of 3M. Company faces a difficult decision: to trace and discriminate any such endeavour or allow consciously pursuing of those innovation drivers.

The research presented in this paper analyses the background and conditioning of the persons involved in the INPs. Typical cases of BMW and glue manufacturer are presented. Based on literature survey and developed phenomenological classification, an analysis of an innovative engagement, the personality traits, company organization and culture, motivators and showstoppers impact is performed. The mutual interdependence and suitable areas of innovative company activities concludes the paper.

An innovation pursue with the INP projects as a part of a deal, both, in large and small companies is recommended. Yet, the approach of large enterprises shall differ from that of micro, small and medium companies, taking into account the human factor traits of potential INP project managers.
\end{abstract}

Keywords-Phenomenological classification; Team Centred Interaction; Innovative non-existent projects taxonomy; engagement model; Motivation factors

\section{INTRODUCTION}

Up to $15 \%$ of innovation in the companies origins from the non-institutional sources according to the survey conducted among 722 top managers [1]. Same time Groger [2] claims that only $9 \%$ of the companies know the number and the progress of the projects, realized in the company. These noninstitutional sources of innovation are presumed to be hidden in the area of the unknown to the company management employees' activities.

This paper presents a research of the phenomena and the contribution of such Innovative Non-existent Projects, called hereafter INP, to the industry innovation. After the literature survey outlined in the next Chapter the research methodology is described and the theoretical background for further considerations is developed. The above described innovative engagement of our lady project manager is subsequently modelled and operationalized. The generalization of the selected model components allows for the identification of the situation and persons with a potential for such Innovative Non- existent (oh, really?) Projects. Implications for the enterprises close the paper.

\section{LITERATURE SURVEY}

There is almost no traceable literature on innovative nonexisting projects. The issue remains vastly unrecognized. The systematic literature review SLR [3.4] covered sparely available analyses, surveys results and best practice advices.

The unknown sources of innovation, the unknown projects, comprise the Innovative Non-existent Projects INP. In literature various terms are used to describe this grey area in the companies: bootlegging [5,6,7], bootlegged [8], smuggled [9] or even skunk [10] projects. In German literature, widely the English bootlegging or U-Boot terms are used [10,11].

For the purpose of this paper the definition of the R\&D INP project of Augsdorfer [12] and Michalik [11] has been adopted: An INP project is an innovative endeavour undertaken in a broadly understood interest of the employer by a highly motivated, enterprise oriented employees, who defined by themselves and realized without any consents of the company management this undertaking.

Augsdörfer and Michalik placed the INP projects in context with an approach of defining the mechanisms leading their emergence. Sakhardari and Bidakhavidi, Criscuolo et al., Augsdorfer, Michalik indicate that the personality, motivation and organizational factors are key impact factors in the causality of the INP projects. Subsequently a model of the innovative engagement which includes these three components has been developed and instrumentalized.

Criscuolo demonstrated the relevance of the INP projects to the company innovation through greater autonomy of the R\&D staff in proactive development of the individual and not formalized personal research agendas.

Several authors estimate that up to $20 \%$ of the R\&D capacity in the company is consumed by the INPs $[10,11,12,13,14]$. However, the performance of these INP projects is higher as compared to the institutional innovation projects, as the inventors focus on absolutely indispensable and target oriented activities. Just to recall the above example of the new glue, Macrolon $\AA$, Bayer Aspirin $\AA$, Post-it $\AA$ of $3 \mathrm{M}$ or new 12 cylinder engine of BMW. According to Michalik $54 \%$ of successfully introduced in market INP projects are of incremental nature (34 \% improvements, $20 \%$ error 
corrections), $5 \%$ are the integrative innovation (new products) and the rest is within the transformative innovation (40\% basic research, $1 \%$ scientific work).

Based on these provisions a research method had been chosen as presented in the subsequent chapter.

\section{SELECTED METHODOLOGICAL APPROACH}

The research question focuses on "What?" and "How?" leaving purposely the causal and conditional "Why?" for further research [15]. No claim of completeness, neither orthogonality is raised in this paper.

The SLR had been conducted taking the following criteria under considerations:

- Is there one theory or practice identifying and approaching the problem of the non-existent innovative projects?

- What are the factors leading to this type of projects?

- Which personality characterizes the INP-project manager?

In the assessment of the contents, priority is given to the contents intention over the pure semantics. Excluded are the issues of gender and cultural heritage impact. The research focuses on the project emergence conditions and the personality of the person engaged in such an endeavor.

The research method bases on the qualitative approach by Michalik targeted in exploration of the mechanisms, which trigger the INP projects emergence and the personality of the persons, which get engaged in these endeavors. The results from 266 surveyed persons are correlated and validated. In order to assure the completeness of the considerations the phenomenological classification, presented in the next chapter, had been developed. Further, the INP projects are classified according to the time of their openness in the whole life cycle.

A model of the innovative engagement, which includes the personality, motivation and organizational factors in the causality of the INP projects, has been developed. The empirical results of Michalik had been validated against the literature sources $[5,16]$.

Paper concludes with the handling recommendations for the organizations with the INP projects.

\section{PHENOMENOLOGICAL CLASSIFICATION}

Team Centered Interaction model TCI has been chosen as a comprehensive behavioral reference to an individual, placed in social and material environment [17], as it occurs with INP engaged person. In this model focus of personal orientation is either on personal topics ("I"), on interaction with others ("We" replaced here for differentiating purposes with "Team", $\mathrm{T}$ ) or on common goal ("It", replaced for the same reason with "Goal" G). The environment ("World", W) is taken under considerations in closest, as well as in broad, meaning into account, while considering each of the perspectives I, We (Team) or Goal (It). The cognitive processes permanently rotate: while focusing on "I" we influence our "We" thinking,
"We" thinking leads to common goal focusing ("Goal") and goal oriented thinking influence back our egocentric orientation. All biased by the "World". According to Cohn an individual and the team are successful when for each team member including the leader, all items are in balance [idem] The person engaged in an INP project with team composed of family, family business managers and shareholders forms a TCI model. This justifies the choice of TCI for the phenomenological classification. The engagement, stipulated by the cognitive process, is conditioned by:

- the Willingness/Courage of the person

- Capabilities/Potential of the person

- Feasibility to act [18]

The correlation of both: the cognitive process and the engagement conditions resulted in the matrix presented in the Table I further down. This systemic approach help to secure the completeness of the considerations, related to the personalities of the person engaged in the INP endeavor.

TABLE I. PHENOMENOLOGICAL PERSONALITY INTERDEPENDENCES

\begin{tabular}{|c|c|c|c|c|}
\hline & (I) & (We) & (Goal) & (World) \\
\hline $\begin{array}{l}\text { Dimensio } \\
\mathrm{n}\end{array}$ & $\begin{array}{l}\text { Innovator } \\
\text { personality } \\
\text { orientation }\end{array}$ & $\begin{array}{l}\text { Innovator } \\
\text { working } \\
\text { place } \\
\text { relationship } \\
\text { orientation }\end{array}$ & $\begin{array}{l}\text { Attitude } \\
\text { towards } \\
\text { the goal }\end{array}$ & $\begin{array}{l}\text { Innovator } \\
\text { Environ- } \\
\text { ment } \\
\text { orientation }\end{array}$ \\
\hline $\begin{array}{l}\text { Willingne } \\
\text { ss } \\
\text { /Courage }\end{array}$ & $\begin{array}{l}\text { 1.Intrinsic } \\
\text { motivation }\end{array}$ & $\begin{array}{l}\text { 4.Extrinsic } \\
\text { family and } \\
\text { managemen } \\
t \text { motivation }\end{array}$ & $\begin{array}{l}\text { 7.Risk } \\
\text { taking } \\
\text { willingness }\end{array}$ & $\begin{array}{l}\text { 10.Extrinsic } \\
\text { world } \\
\text { motivation }\end{array}$ \\
\hline $\begin{array}{l}\text { Capabiliti } \\
\text { es } \\
\text { /Potential }\end{array}$ & $\begin{array}{l}\text { 2.Knowled } \\
\text { ge and } \\
\text { capabilities }\end{array}$ & $\begin{array}{l}\text { 5.Relations } \\
\text { hip relevant } \\
\text { capa-bilities } \\
\text { in } \\
\text { managemen } \\
\mathrm{t}\end{array}$ & $\begin{array}{l}\text { 8.Goal } \\
\text { achievemen } \\
\mathrm{t} \text { relevant } \\
\text { capabilities }\end{array}$ & $\begin{array}{l}\text { 11.Availabi } \\
\text { lity and } \\
\text { quality of } \\
\text { the suitable } \\
\text { tools }\end{array}$ \\
\hline $\begin{array}{l}\text { Feasibilit } \\
\text { y }\end{array}$ & $\begin{array}{l}\text { 3.Creativity } \\
\text {, organiza- } \\
\text { tional } \\
\text { adaptation } \\
\text { capability }\end{array}$ & $\begin{array}{l}\text { 6.Allowanc } \\
\text { e \& } \\
\text { psycho- } \\
\text { logical } \\
\text { support of } \\
\text { family and } \\
\text { managemen } \\
\text { t }\end{array}$ & $\begin{array}{l}\text { 9.Attainabi- } \\
\text { lity }\end{array}$ & $\begin{array}{l}\text { 12.Access } \\
\text { and } \\
\text { conscious } \\
\text { support for } \\
\text { the leader }\end{array}$ \\
\hline
\end{tabular}

V. INNOVATION AND NON-EXISTENT PROJECTS

In this chapter the relation between the innovation and the non-existent innovative projects INP is explored in view of the phenomenologically relevant factors.

It was already over 100 years back, when Joseph Schumpeter defined an innovation as a new product or service, created on the base of the existing economical possibilities, which successfully conquered the market [19]. Similarly the success on the market is the determinant of an innovation [20].

Three types of innovation may be distinguished:

- Incremental innovation - when existing product is gradually improved (even such small steps means e.g. in automobile industry dozens of new patents). 
- Integrative innovation - when two existing products are combined to a new innovative product or service (this is the closest case of Schumpeter definition, e.g. social platforms)

- Transformative Innovation - mostly associated with the process change, when new products and services, leading to the faster or cheaper realization of the targets, are introduced on the market.

Innovation has a character of a cyclical process, which changes the patterns. The creative destruction of the replaced patterns means certain power to overcome the resistance is needed.

The analysis of the INP cases, augmented by the literature survey, leads to the conclusion, that employees engage themselves in such endeavour, when there is a deficit in one or more of the following dimensions:

- Interaction quality (human interrelations prohibit free exchange of thoughts)

- Information quality (the exchanged information is incomplete or erroneous)

- Job allocation quality (underused capabilities, frustration aroused from that fact)

- Product portfolio quality (employees sees potentially better market orientation)

Missing Quality in one of the dimensions usually has the consequence of the deficit in on or more other dimensions: insufficient interaction quality leads to the inferior information quality, which in turn might result in inappropriate job allocation and wrong product portfolio because of missing competence.

The INP projects are classified according to the stages of their open existence within the organization (Fig. 1).

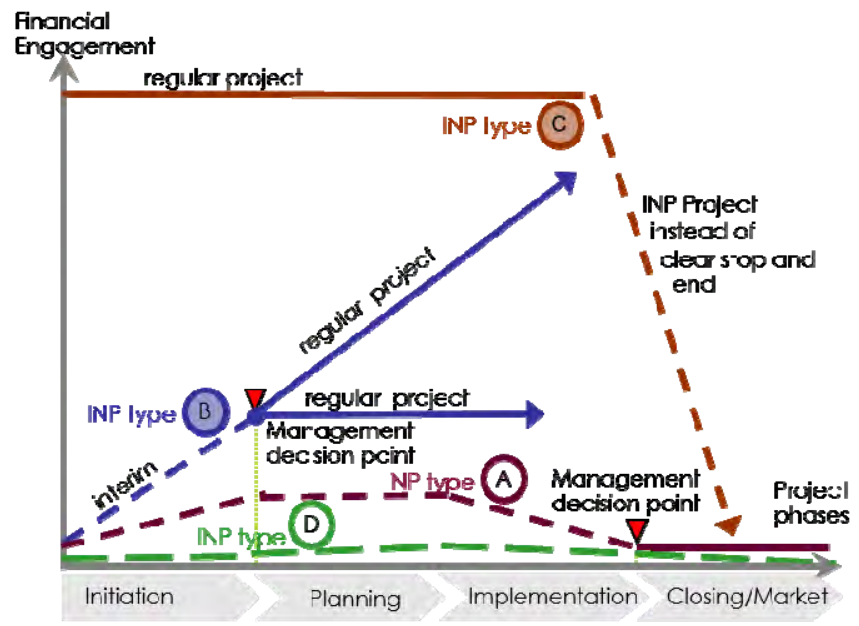

Fig. 1. INP Taxonomy.

Project phases known to the company management are drawn with a solid line. The unknown phases are marked with interrupted lines.
INP of type $\mathrm{C}$ runs as regular project the first three phases. Then, instead of clear stop and end it convert to the INP project, to surface again as a regular project in some later phase. The initially appropriate budgets are usually reduced significantly until the market introduction.

INP of type A runs from the Initialization through all the phases until the Implementation phase produces the marketable product: Then, upon decision of the management, it becomes the regular last phase as seen by the project, first, as seen by the management, phase of market introduction. The glue of Dr Spencer Silver, key of Post-it ${ }^{\circledR}$ notes, is one of the examples [21].

Most of the INPs, in particular those of the transformative innovation (basic research, scientific work) are projects of type B. Those INPs are initiated by the employees, with sometime silent approval of unspecified resources deployment by the company management. These projects surface in success case [22] or are solicited after the allowed budget for unspecified efforts had been used [23, 24]. Upon management evaluation project may follow the original INP budget or win additional resources along the company guidelines. The economic contribution of these projects is enormous. Mayer, VicePresident of Google in charge of product and users research, claims that $50 \%$ of all Google innovations are originally the type B INPs [14]!

The last group - type D INPs are projects, which never managed to be discovered or surfaced into the light lime. All project phases remains obscure to the company management. Yet, giving the credibility to the research by Michalik, they outnumber all the other type INPs together.

In context of the presented above relevance of the INP projects to the innovation capabilities of an organization and taxonomy, which specifically address the INP open phases, a model of innovative engagement is presented and operationalized in the next chapter.

\section{INNOVATIVE ENGAGEMENT OF INP PARTICIPANTS}

The above characteristics of the INPs demands a particular attitude of the persons engaged in such INP endeavors. Michalik defines innovative engagement as a voluntary, conscious, long term participation in the process of innovation creation, entered upon own incentive by ambitious and risk prone individuals with high persistence and capability for at least time limited intensified innovation activities. These individuals are further called the innovators. Their Engagement is affected by:

- The Willingness /Courage: Innovator faces numerous obstacles, enters high risks,

- The Capabilities/Potential: Knowledge and Skills of those involved in INP,

- The Feasibility: Creativity, cognitive abilities and permissive set-up for an INP.

An impact of the personality of the involved person, company environment and the relationship with others at the 
working place on each of these dimensions is given in the phenomenological Table I above.

In operationalization model, the behavior conditioned by the willingness/courage is listed as the innovation attitude. The behaviors conditioned by the capabilities/potential are grouped as innovation aptitude. The extrinsic motivation stimulates the innovative atmosphere, resulting from the imposition of the innovator personality and the environment innovation orientation. This confirms also the research results of Sakhdari and Bidakhvidi [5]. The final innovative engagement is conditioned by the barriers, both in the personality as well as in the environment. Fig. 2 gives the variables conducive to the INP emergence.

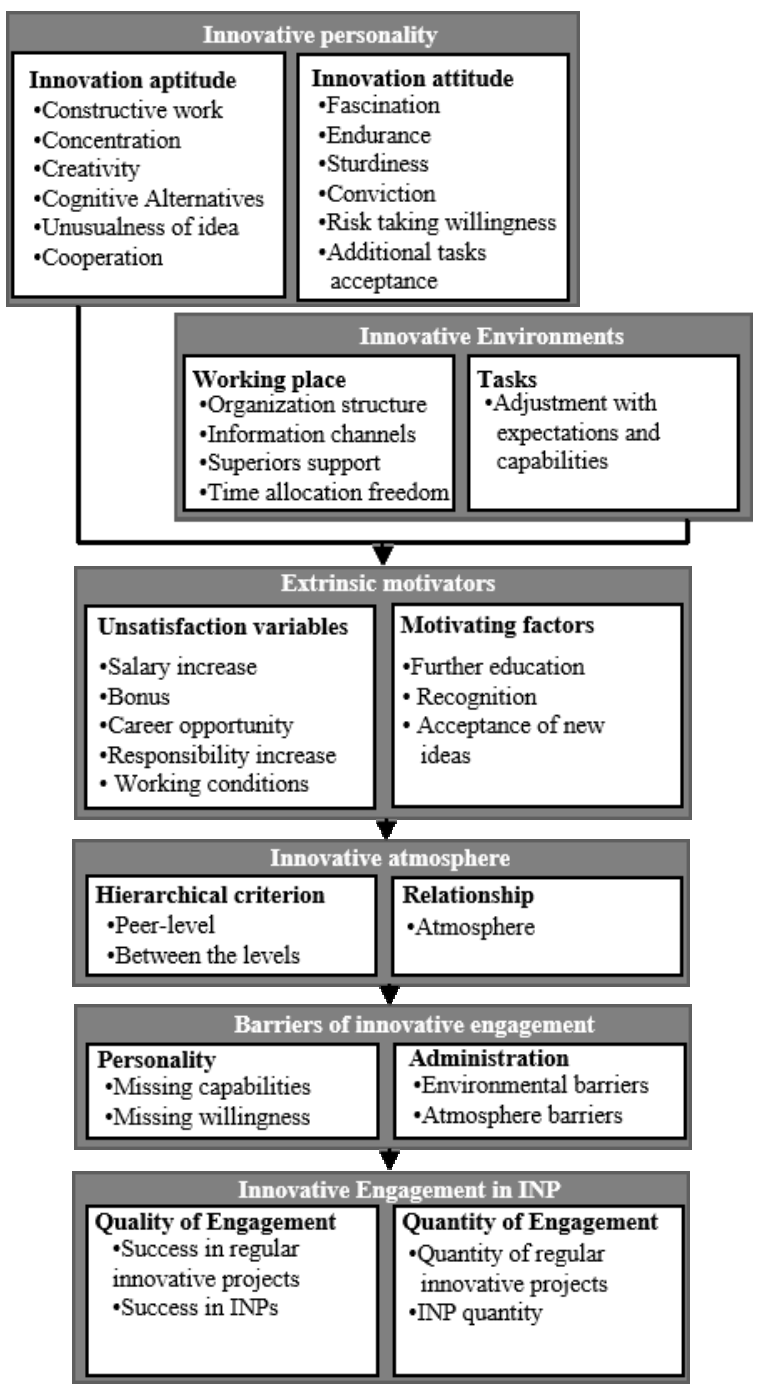

Fig. 2. Variables conducive to the INP emergence.

The factorial analysis leads to the clustering and the identification of the main factors, which impacts the innovative engagement. The final evaluation criterion of INP economic and technological success is the quality of innovative engagement in the INP.
An analysis of the interdependencies between those factors indicates the direct impact of the goal orientation of the innovator on his salary and status. This is evident in regular innovative projects, where innovator has the opportunity to distinguish himself from the others. Weak correlation (correlation coefficient) between the goal orientation and flexibility/personal development opportunities suggests, that the goal oriented innovator put less value on the last.

The high stakes of status and salary corresponds to the direct correlation with the organization structure: salary and status dominate as the main motivational factors even in the most innovative enterprises. Simultaneously the weak correlation between the salary/status and the innovation (organization culture) demands a high sensitivity of superiors to recognize the innovative personality among the employees and to act in a right way.

Nonconformists, as could be expected, do not put much value on salary, but - what might surprise - maintain excellent relationships both with their superiors and with colleagues. Possible explanation might be rather the desire of nonconformists involved in the INPs to share their ideas with their colleagues, than to swagger around. Their good relationship with the superiors may be explained with their desire to cover the clandestine INP activity with perfect communication with the superiors intended to shift their attention beyond any suspicions.

The creativity of the INP nonconformist innovators in general impacts positively also the overall relationships between the colleagues and superiors. Further, the positive correlation with the personal development opportunity indicate, that the INP innovators favors the coaching leadership (delegating style) rather than the participative one [25].

Work engagement, which has positive impact on the relations both with the colleagues and with the superiors, in correlation with high competence of the INP innovators in problem solving, create excellent set-up for the progress in an innovative process: both in regular and in the INP projects.

Summarizing we conclude, that the major positive impact innovation engagement and success have:

- Work engagement

- Personal development opportunities and

- Organizational culture

Whereas the highest negative impact have:

- Salary and

- Status

The interdependence between the personality factors, engagement and motivation factors is given in Table II. 
TABLE II. INTERDEPENDENCE BETWEEN THE PERSONALITY, ENGAGEMENT AND MOTIVATION FACTORS

\begin{tabular}{|c|c|c|c|c|c|c|c|c|}
\hline \multirow[t]{2}{*}{$\begin{array}{r}\text { Influ- } \\
\text { ence }\end{array}$} & \multicolumn{2}{|c|}{ Engagement } & \multicolumn{4}{|c|}{ Motivation Factors Impact } & \multicolumn{2}{|c|}{$\begin{array}{c}\text { Organizatio } \\
\text { n Culture }\end{array}$} \\
\hline & $\begin{array}{l}\text { Dire } \\
\text { ctly }\end{array}$ & $\begin{array}{l}\text { In- } \\
\text { direc } \\
\text { tly }\end{array}$ & $\begin{array}{l}\text { Wor } \\
\text { k- } \\
\text { time } \\
\text { Flexi } \\
- \\
\text { bilit } \\
\text { y } \\
\end{array}$ & $\begin{array}{l}\text { Salar } \\
\mathrm{y}\end{array}$ & $\begin{array}{l}\text { Pers } \\
\text { onal } \\
\text { Dev } \\
\text { elop- } \\
\text { ment }\end{array}$ & $\begin{array}{l}\text { Statu } \\
\mathrm{s}\end{array}$ & $\begin{array}{l}\text { Rela } \\
\text {-tion } \\
\text { with } \\
\text { colle } \\
- \\
\text { ague } \\
\text { s }\end{array}$ & $\begin{array}{l}\text { Rela } \\
\text {-tion } \\
\text { with } \\
\text { supe } \\
\text { r- } \\
\text { viors }\end{array}$ \\
\hline $\begin{array}{l}\text { Goal } \\
\text { Orie } \\
\mathrm{n}- \\
\text { tatio } \\
\mathrm{n}\end{array}$ & - & - & + & + & 0 & + & - & - \\
\hline $\begin{array}{l}\text { Non- } \\
\text { Conf } \\
\text { ormi } \\
\text { sm }\end{array}$ & - & + & 0 & 0 & + & - & + & + \\
\hline $\begin{array}{l}\text { Crea } \\
\text { ti- } \\
\text { vity }\end{array}$ & - & + & 0 & 0 & + & - & + & + \\
\hline $\begin{array}{l}\text { Wor } \\
\mathrm{k} \\
\text { Enga } \\
\text { - } \\
\text { gem } \\
\text { ent }\end{array}$ & + & + & + & 0 & + & - & + & + \\
\hline
\end{tabular}

\section{CONCLUSIONS}

"An enterprise, which pursue the innovation enters irrevocably the risks. An Enterprise which does not risk the innovation, cease to exist". Dornberger attribute this statement to Ferdinand Piech of VW [26]. Authors of this paper could not trace the original source, yet fully share this opinion. Enterprises are condemned to innovation. How shall they proceed?

- In view of the above analysis, it is recommended to create an atmosphere of innovation breakout in R\&D teams and to admit certain volume of INP projects. Those, involved in the INPs distinguish themselves by exceptional engagement, both in the regular and in the INP projects. Innovators deliver better quality results. BMW in its innovation center in Palo Alto assign each engineer a budget of US \$2500.- for his own (INP) project [24]. Once the budget is reached, the undertaking may be presented in the company. Shall the evaluation be positive - project becomes a regular innovation project. Seldom it reaches the status of an INP type A, but certainly it becomes type B project.

Creative non-conformists, who do engage themselves in their work, carefully coached towards personal development, create the most valuable human capital in the enterprise.

Finally, encouragement to risk taking and high tolerance of erroneous steps are the core of an innovative organization culture.

- Leading innovative enterprises: Apple, Google, 3M apply the rule of " $15 \%$ ": Employees in R\&D can spend up to $15 \%$ of their working time on INP projects $[12,27,28]$. There is a danger, that at this high budget indiscriminately all types INP projects are financed: from A to D type. The innovators with strong personalities will be themselves engaged in the INP type $\mathrm{C}$, not necessary positively contributing to the innovative atmosphere in their teams. However, in view of the examples given in this paper, for the enterprises, which can afford this risk nevertheless it makes sense.

- Majority of worldwide industry are micro, small and medium enterprises (MSME), which simply cannot afford $15 \%$ of uncertain win investment. In this group authors recommend to apply the results presented in this paper: to analyze the personalities of the employees and how their interests matches the needs of an enterprise. Only type B INP are affordable innovation margin. Discovered INP type A and C shall lead to some sort of penalization as a warning towards all undetected type D INPs. However, this influence negatively the innovation atmosphere in the enterprise; Therefore, a careful weighting of the penalties is necessary. Such a "controlled" INPs are feasible by consequent progress control, best - by applying consequently in all real projects a fine grid earned value analysis. Here the competence of the evaluation team substantially contributes to the quality of the current results estimation. It is more likely, that the colleagues in team possess higher competence in the field, than the superiors. It is thus recommendable to entrust the team with the mutual results evaluation.

- Summarizing: small enterprise or big corporation: they have to create the innovation atmosphere, evaluate the personalities of the employees and risk certain portion of the INP projects. Raster of progress control in official projects, adjusted to the enterprise financial abilities, shall keep the capital at risk in INP investments under control.

Authors thank the reviewers for their efforts to evaluate this contribution and valuable comments, which led to the significant improvements in the current version.

\section{REFERENCES}

[1] McKinsey, "722 Topmanager Responder in How companies approach innovation: A McKinsey Global Survey," in McKinsey Quarterly, New York, 2007, pp. 3-5.

[2] M. Gröger, Projektmanagement: Abenteuer Wertvernichtung, University of Applied Sciences, Munich, 2004, pp. 6-8.

[3] R.F. Baumeister, Writing a literature review, The portable mentor: Expert guide to a successful career in psychology. 2nd ed., Springer New York, 2012, pp. 119-132.

[4] B. Kitchenham, B. Pearl, D. Budgen, M. Turner, J. Bailey, and S. Linkman, "Systematic literature reviews in software engineering," Information and Software Technology, vol. 2009 (51), pp 7-15, January 2009.

[5] K. Sakhdari and E.J. Bidakhavidi, "Underground Innovation: How to Encourage Bootlegging Employees to Disclose Their Good Ideas", Technology Innovation Management Review, vol. 6(3), pp. 5-12, March 2016.

[6] P. Criscuolo, A. Salter, and ALJ. Ter Wal, "Going Underground: Bootlegging and Individual Innovative performance", Organization Science, vol. 25(5), pp. 1287-1305, September-October 2014.

[7] PJ. Rea and H. Kerzner, Strategic Planning: A Practical Guide, John Wiley Hoboken 1997, pp. 196. 
[8] M. Dodgson, D. Gann, and A.J. Salter, The management of technological innovation: strategy and practice, Oxford University Press, New York, 2008, pp. 180.

[9] K.E. Knight, "A descriptive Model of the Intra-firm Innovation Process," The Journal of Business, vol. 40(4), pp. 479, October 1967.

[10] J. Jaworski and F. Zurlino, Innovationskultur: vom Leidensdruck zur Leidenschaft; wie Top-Unternehmen Ihre Organisation mobilisieren, Campus Verlag, Frankfurt, 2007, pp. 125.

[11] C. Michalik, Innovatives Engagement, Eine empirische Untersuchung zum Phänomen des Bootlegging, Deutscher Universitäts-Verlag, Wiesbaden, 2003, pp. 5- cont..

[12] P. Augsdorfer, "Bootlegging and path dependency," Research Policy, vol. 34(1), pp. 1-11, February 2005.

[13] J. Berke, Geheimbund der Genies, Wirtschaftswoche 31, WW Frankfurt, pp. 52-54, July 1992.

[14] B. Casnocha, "Success on the Side," The American: The Journal of the American Enterprise Institute, v2009, pp. 1-10, April 2009.

[15] J. Meredith, "Building Operations Management Theory through Case and Field Research," Journal of Operations Management, vol. 16(4), pp. 441-454, April 1988.

[16] M. Van Herpen, M. Van Praag, and K. Cools, "The effects of performance measurements and compensation on motivation: an empirical study," De Economist, vol. 3, pp. 303-329, September 2005.

[17] R.C. Cohn, Von der Psychoanalyse zur Themen zentrierten Interaktion: von der Behandlung einzelner zur einer Pädagogik für alle, Klett-Cotta, Stuttgart, 1975/2009, pp.3- cont.

[18] F. Ion and M. Brand, Motivorientiertes Führen: Führen auf Basis der 16 Lebensmotive nach Steven Reiss, Gabal, Offenbach, 2009, pp.18.
[19] J. Schumpeter, Theorie der wirtschaftlichen Entwicklung, Duncker und Humbold, Leipzig, Berlin, 1912/2006, pp. 3- cont.

[20] K.E. Knight, "A descriptive Model of the Intra-firm Innovation Process," The Journal of Business,vol. 40(4), pp. 479, October 1967.

[21] S. Zumdahl and D.J. DeCoste, Chemical Principles, Cengage Learning, Belmonte, 2013, pp. 11-14.

[22] W. Zanker, Innovation in der BMW-Gruppe, Referat TU Berlin 12.06.2007, BMW, Munich, 2007, pp. 1- cont.

[23] S. Schmudermaier, Aus Freude am Tüfteln," in Motorline CC, Wolfsgraben, 2010 , pp. https://www.motorline.cc/autowelt/news/2010/BMW/25-Jahre-BMWForschung-und-Entwicklung-Aus-Freude-am-Tüfteln-155941.html, accessed November 10, 2018

[24] S. Schmudermeier, Außenstelle im Silicon Valley,“ in Motorline CC, Wolfsgraben, 2010 , pp. http://www.motorline.cc/autowelt/index.php/25-Jahre-BMW-Forschungund-Entwicklung---Aus-Freude-amT\%25C3\%25BCfteln/article=155941, November 10, 2018.

[25] B. Lent, Cybernetic Approach to Project Management, Springer, Berlin New York, 2013, pp. 399-426

[26] P. Dornberger, Innovation Management, FHNHW, Basel-Olten, 2006, pp. 3.

[27] V. Govindarajan and S. Srinivas, "The innovation Mindest in Action: 3M Corporation," Harvard Business Review, pp. 1, August 2013, http://www.3m.com/cms/CA/en/1-30/iiFRuFM/view.html, 20, accessed November 10, 2018.

[28] E. Gundling, "The 3M Way to Innovation: Balancing People and Profit," Kodansha Intl Ltd., Tokyo, 2000, pp. 302. 